\title{
Kinesio Taping®: Como e quando utilizar no ambiente hospitalar
}

\author{
Rodolfo Silva Kós ${ }^{1}$
}

\section{Resumo}

Introdução: O Kinesio Taping ${ }^{\circledR}(\mathrm{KT})$ é uma técnica relativamente nova, utilizada como ferramenta auxiliar em programas de tratamento em reabilitação. A bandagem elástica quando aplicada corretamente, é capaz de aprimorar o controle voluntário e melhorar a coordenação através da estimulação de receptores cutâneos. Objetivo: Exposição de possíveis técnicas, cuidados e orientações à família e à equipe sobre a utilização do método Kinesio Taping ${ }^{\circledR}$ na criança hospitalizada. Metodologia: Revisão de literatura feita de 2006 a 2014 nas bases de dados Medline e Google Scholar. Resultados: Na base de dados Medline foram encontrados 3 artigos com os descritores "kinesio taping children", onde 1 artigo foi utilizado. No Google Scholar com os descritores "kinesio taping pediatrics" foram encontrados 38 artigos, nos quais 1 foi selecionado para o presente resumo, além dos descritores "crianças prevenção lesões de pele adesivo", com 75 resultados e 1 artigo selecionado. Os artigos foram escolhidos de acordo com o conteúdo e a relevância para este estudo. Discussão: O método Kinesio Taping $®$ conta com objetivos diversos, e dentro do contexto da hospitalização, é necessário que a equipe seja instruída com relação a o que é a bandagem, quais são os objetivos terapêuticos e formas de retirá-la sem haver episódios de lesão de pele. Assim, deve ser realizada avaliação da condição física, de posicionamento e manipulação do paciente, além da inspeção da região a ser aplicada a bandagem, observando espessura da pele, hidratação, lesões pré-existentes, acessos venosos, ostomias, sondas, drenos e demais apêndices. Após avaliação criteriosa, realizar a aplicação que mais beneficiaria o indivíduo em determinada fase do tratamento. Conclusão: O KT é um método comprovadamente eficaz em pediatria, sendo benéfico para a criança hospitalizada por proporcionar estimulação contínua, mantendo ou potencializando objetivos pré-determinados por parte da reabilitação motora.

Palavras chave: modalidades de fisioterapia, hospitalização, pediatria.

Kós, Rodolfo Silva. "Kinesio Taping ${ }^{\circledR}$ : Como e quando utilizar no ambiente hospitalar", in Anais do 20. Congresso Internacional Sabará de Especialidades Pediátricas

\footnotetext{
${ }^{1}$ Fisioterapeuta graduado pela Universidade Paulista, especialista em Fisioterapia e Reabilitação aplicados à Neurologia Infantil pela Faculdade de Ciências Médicas da Universidade Estadual de Campinas - UNICAMP, mestrando em Ciências da Cirurgia pela Faculdade de Ciências Médicas da UNICAMP.
} 


\title{
Kinesio Taping ${ }^{\circledR:}$ How and when to use in the hospital environment
}

\begin{abstract}
:
Introduction: The Taping ${ }^{\circledR}$ Kinesio $(\mathrm{KT})$ is a relatively new technique, used as an aid in treatment programs in rehabilitation. The elastic bandage when applied correctly, can improve voluntary control and coordination through stimulation of cutaneous receptors.
\end{abstract} Objective: Exposure of possible techniques, care and guidance to the family and staff on the use of Kinesio Taping ${ }^{\circledR}$ method in hospitalized children. Methodology: Literature review done from 2006 to 2014 using the Medline and Google Scholar data. Results: In Medline, 3 articles were found with the descriptors "kinesio taping children", where one was used. Google Scholar with the keywords "pediatrics kinesio taping" 38 articles, in which one was selected for this summary, besides the descriptors found "children preventing skin lesions adhesive", with 75 results and one selected article. The articles were chosen according to content and relevance for this study. Discussion: The Kinesio Taping ${ }^{\circledR}$ method has several objectives, and within the context of hospitalization, it is necessary that staff be educated about what is the bandage, which are the therapeutic goals and ways to remove it without having episodes of skin injury. Thus, evaluation of the physical condition, positioning and handling of the patient should be performed in addition to the inspection of the region where the bandage will be applied, noting skin thickness, hydration, pre-existing lesions, venous access, ostomies, catheters, drains and other appendices. After careful evaluation, perform the application that will most benefit the individual at any stage of treatment. Conclusion: The KT is a proven method in pediatrics, being beneficial to hospitalized children by providing continuous stimulation while maintaining or enhancing goals predetermined by the motor rehabilitation.

Keywords: physiotherapy modalities, hospitalization, pediatrics.

\section{Referências}

Ruiz AR. Eficacia del kinesiotape ${ }^{\circledR}$ como terapia complementar em niños que presentan espasticidad. Lérida 2014. Graduação (Fisioterapia). Faculdade de Enfermagem da Universidade de Lleida. 
Pavia A, Damasceno VAM, Kós RS. Efeitos do Kinesio Taping ${ }^{\circledR}$ para benefício da extremidade superior em criança hemiparética: Estudo de caso. I Congresso Brasileiro de Kinesio Taping®. 2013; São Paulo.

Fontenele FC, Cardoso MVLML. Lesões de pele em recém-nascidos no ambiente hospitalar: tipo, tamanho e área afetada. Rev Esc Enferm USP. 2011; 45(1): 130-7.

Yasukawa A, Patel P, Sisung C. Pilot Study: Investigating the effects of Kinesio Taping ${ }^{\circledR}$ in an acute pediatric rehabilitation setting.The American Journal of Occupational Therapy. 2006; 60(1): 104-10. 